\title{
CRITICAL THINKING SKILLS OF ACCOUNTING STUDENTS
}

\author{
HABILIDADES DE RACIOCÍNIO CRÍTICO DE \\ ALUNOS DE CONTABILIDADE
}

\section{HABILIDADES DE RACIOCINIO CRÍTICO DE ALUMNOS DE CONTABILIDAD}

\author{
EDGARD B. CORNACHIONE, JR. \\ $U$. of Sao Paulo/Brazil (Associate Professor) \\ \& U. of Illinois at Urbana-Champaign/USA \\ edgard@uiuc.edu \\ JOHN R. DUNCAN \\ Clemson University/USA (Assistant Professor) \\ \& U. of Illinois at Urbana-Champaign/USA \\ jrd@clemson.edu \\ SCOTT D. JOHNSON \\ University of Illinois at Urbana-Champaign/USA \\ (Full Professor and Department Head) \\ sjohnson@uiuc.edu
}

\begin{abstract}
Educational systems around the world judge student academic performance based upon reading and writing abilities, with evidence of critical thinking playing an essential role. In order to improve business education, a better understanding of students' critical thinking and communication skill is required. This study aimed at assessing reading, writing, and critical thinking skills of accounting students using validated instruments: (a) Motivated Strategies for Learning Questionnaire, (b) Ennis-Weir Critical Thinking Essay Test,
\end{abstract}




\section{repc}

and (c) Flesch Reading Ease (English and Portuguese). Students wrote a short essay that was evaluated for writing quality and critical thinking based on the EW-CTET. Scores provided indications of good writing quality and evidence of high levels of critical thinking. No significant differences (i.e., gender, parenthood, program level, and program stage) of measured reading levels of the written products were found. Elements for improving learners' performance aligned with their critical thinking skills are discussed along with a deep reflection on how educators would behave as agents of change in the reported scenario. Observed cultural differences in critical thinking related to perception of authority should be examined in further investigations.

Keywords: Accounting. Critical Thinking. MSLQ. Ennis-Weir. Reading and Writing Abilities. Flesch.

\section{RESUMO}

Sistemas educacionais ao redor do mundo avaliam o desempenho acadêmico de alunos com base em habilidades de leitura e redação, com evidências sobre o papel essencial do raciocínio crítico. Para aprimorar a educação na área de negócios é necessário melhor entendimento sobre o raciocínio crítico dos alunos, bem como sobre suas habilidades de comunicação. Esta pesquisa focou na avaliação de habilidades de leitura, redação e raciocínio crítico de alunos de contabildiade utilizando instrumentos validados: (a) Questionário de Estratégias Motivadoras para Aprendizagem (Motivated Strategies for Learning Questionnaire, MSLQ), (b) Teste Escrito de Raciocínio Crítico de Ennis-Weir (Ennis-Weir Critical Thinking Essay Test, EW-CTET), e (c) Indicador Flesch de Facilidade de Leitura (Flesch Reading Ease, em Inglês e versão adaptada para o Português). Os participantes escreveram uma pequena redação que foi avaliada em termos de qualidade de escrita e raciocínio crítico com base no EW-CTET. Os resultados trouxeram indicações de boa qualidade de escrita e evidência de níveis elevados de raciocínio crítico. Diferenças significativas (e.g., gênero, maternidade/paternidade, nível de estudos, e estágio no programa) não foram observadas nas métricas sobre níveis de facilidade de leitura dos produtos escritos gerados pelos participantes. Elementos para o aprimoramento de desempenho dos participantes alinhados com suas habilidades de raciocínio crítico são discutidos juntamente com reflexão profunda sobre comportamento de educadores como agentes de mudança neste cenário. Sugere-se que diferenças culturais sobre raciocínio crítico observadas neste estudo relacionadas com a percepção de autoridade sejam examinadas em futuras investigações.

Palavras-chave: Contabilidade. Raciocínio Crítico. MSLQ. Teste Ennis-Weir. Habilidades de Leitura e Redação. Indicador Flesch. 


\section{RESUMEN}

Sistemas educacionales alrededor del mundo evalúan el desempeño académico de alumnos con base en habilidades de lectura y redacción, con evidencias sobre el papel esencial del raciocinio crítico. Para apurar la educación en la área de negocios es necesario un mejor entendimiento sobre el raciocinio crítico de los alumnos, así como sobre sus habilidades de comunicación. Esta pesquisa se centró en la evaluación de habilidades de lectura, redacción y raciocinio crítico de alumnos de contabilidad utilizando instrumentos validados: (a) Cuestionario de Estrategias Motivadoras para Aprendizaje (Motivated Strategies sea Learning Questionnaire, MSLQ), (b) Prueba Escrita de Raciocinio Crítico de Ennis-Weir (Ennis-Weir Critical Thinking Essay Test, EW-CTET), y (c) Indicador Flesch de Facilidad de Lectura (Flesch Reading Ease, en Inglés y versión adaptada para el Portugués). Los participantes escribieron una pequeña redacción que fue evaluada en términos de calidad de escritura y raciocinio crítico con base en el EW-CTET. Los resultados trajeron indicaciones de buena calidad de escritura y evidencia de niveles elevados de raciocinio crítico. Diferencias significativas (por ejemplo, género, maternidad/paternidad, nivel de estudios, y nivel en el programa) no fueron observadas en las métricas sobre niveles de facilidad de lectura de los productos escritos generados por los participantes. Elementos para el esmero de desempeño de los participantes alineados con sus habilidades de raciocinio crítico son discutidos juntamente con ponderación profunda sobre comportamiento de educadores como agentes de cambio en este escenario. Se sugiere que diferencias culturales sobre raciocinio crítico observadas en este estudio relacionadas con la percepción de autoridad sean examinadas en futuras averiguaciones.

Palabras-Clave: Contabilidad. Raciocinio Crítico. MSLQ. Test Ennis-Weir. Habilidades de Lectura y Redacción. Indicador Flesch.

A recent review of accounting education research cites a need for research in areas influencing student performance and assessment (Paisey \& Paisey, 2004). Academic success or failure has both an emotional and a financial impact on students, teachers, and educational institutions (Gracia \& Jenkins, 2001). In order to understand ways to promote student success in accounting programs, it is first necessary to review what success consists of in terms of ideal outcomes. Wilson (2002) promotes a view of accounting education as a multi-disciplinary group of competencies including technical, interpersonal, and creative thinking skills. Another key viewpoint comes from potential employers. Baldwin and Ingram (1991) described ideal accounting students as people with "creative problem-solving skills who can work successfully with diverse and unstructured problems in unfamiliar settings" (p. 1). Consistent across these two 


\section{repec}

viewpoints is the idea that critical and creative thinking are important factors for success in accounting.

Critical thinking is a term that is used widely in both education and accounting, but it is not universally defined. Academics offer a narrow definition of critical thinking while practicing accountants view critical thinking in terms of a holistic set of synergistic competencies (Baril, Wolcott, Bayes, Cunningham, Fordham, and St. Pierre, 1999). Because critical thinking exists along a rich continuum ranging from reliance on empirical sensory inputs to reasoned, probabilistic inquiry it is much simpler to rely on a categorical taxonomy while discussing the development of critical thinking. Originating from the Perry (1970) stage and position model of intellectual and moral development, the Kitchener and King (1981) model establishes seven stages in the development of reflective judgment. They further differentiate reflective judgment from critical thinking by relating it to the resolution of ill-structured problems requiring skills beyond the application of formulae or simple logic. Thus, for the purpose of this paper, critical thinking may be thought of in terms of the identification and resolution of ill-structured problems which require data gathering, analysis, and reflection.

One potential area for research on critical and creative thinking in accounting programs is in the way students interact with text while reading and writing. Typically, student writing is based upon critical reflection on what they have read in a text or other related literature. Both reading and writing require the participant to evaluate arguments on a logical basis as part of a dialogue with a specific audience. As pointed out by $\mathrm{Ng}$, Lloyd, Kober, and Robinson (1999), writing may be evaluated holistically or as a series of isolated skills, a statement that holds equally true for reading. This study supports discussion on the critical thinking skills of accounting students while assessing students' interaction with text in terms of critical thinking, writing, and readability measures.

In business education, this approach is relevant because the presence of written materials throughout the entire decision process is unquestionable. Mingers (2000), relating critical thinking and management, summarized it as "developing the discipline of being skeptical or questioning about statements, propositions or information" ( $p$. 220). While discussing the disciplinary approach of MBA programs, Currie and Knights (2003) stated that one of the main contributions of a more critical approach for business education "is a questioning of the assumptions that are often taken for granted in the disciplinary and staff development approaches" (p. 44). The fact that this is not only a current concern is noteworthy. The American Accounting Association, by 1953, recognized the relevance of this subject when discussing teaching of accounting, set- 
ting special focus on meaning "The teacher must emphasize meaning. He must provide many problem situations both for the application of principles and for practice in reflective thinking" (p. 53).

\section{PROBLEM STATEMENT}

Students' academic performance is closely related to their ability to read and write course materials effectively and to think critically about the information they have read. Although there is considerable existing theory and instruments related to critical thinking development and assessment, Braun (2004) suggests that there is a lack of research on this topic within the field of business education: "empirical assessment data on the success of techniques for developing critical thinking skills are minimal" (p. 235). This is bothersome given that organizations are demanding critical thinking skills from their employees. According to the study by Sormunen and Chalupa (1994), there is an "increasing pressure to produce employees who can think critically" (p. 172).

The purpose of this study was to assess the critical reading, writing, and thinking skills of accounting students at the largest public higher education institution in Brazil; the University of Sao Paulo (USP). The reading, writing, and critical thinking skills of accounting students were assessed using three validated instruments: a) the Motivated Strategies for Learning Questionnaire (MSLQ), b) the Ennis-Weir Critical Thinking Essay Test (EW-CTET), and c) the Flesch Reading Ease (FRE). Comparisons were made based on gender, parenthood, program level, program stage, and measured reading levels of their written products.

\section{RESEARCH HYPOTHESES}

Based on the problem statement and the available literature in the field there is a demand for studies on critical thinking in business education (in particular, in accounting education). This exploratory study was designed based on such demand. Thus, knowing the situation of a particular student in terms of critical thinking is relevant for both student and instructor, once it provides conditions to select and decide on actions that could help improving students' metacognition. It also could support adjusting teaching strategies to provide a better overall learning experience. It is important to consider that critical thinking does not change significantly without specific training. In this case, there is a need to teach and assess critical thinking and not just knowledge and comprehension with occasional application exercises.

In order to provide support to explore connections between critical thinking and reading and writing skills, due to major implications on academic and professional per- 
formance, a set of three instruments were used in this study to collect data from postsecondary students (both undergraduate and graduate levels). Along with the review of the pertinent literature, we gathered evidence that was used to discuss and further explore the following hypotheses.

First, aiming at comparability and contextualization, and due to the use of existing instruments to assess critical thinking in our study, a hypothesis was set to test the similarity of results from this study and those from both the MSLQ-CT and EW-CTET original studies.

$\mathrm{H}_{1}$ : The critical thinking levels of accounting students, based on participants of this study, are equal to those of MSLQ-CT and EW-CTET original studies.

Next, also in terms of comparability and contextualization, and due to the use of an existing instrument to assess quality of writing, a hypothesis was set to test the similarity of the results from this study and the FRE plain text score (both the original study and the version adapted to Portuguese).

$\mathrm{H}_{2}$ : The writing quality levels of accounting students, based on participants of this study, are equal to the suggested FRE plain text score minimums (original and adapted).

A good piece of evidence for both student and instructor, in order to act on the existing teaching and learning process, involving critical thinking and written communication skills is the correlational study with the variables analyzed in this research (MSLQ-CT, EWCTET, FRE Original and FRE Adapted). Thus, a hypothesis was set to test both direction and strength of potential associations between these variables (pairwise).

$\mathrm{H}_{3}$ : There are significant correlations (at the .05 alpha level) between MSLQ-CT, EWCTET and FRE (original and adapted) scores for accounting students, based on participants of this study.

Another important element to help improve the existing teaching and learning process, based on critical thinking and written communication skills, is the comparison of means and analysis of variance involving the variables studied in this research (MSLQ-CT, EW-CTET, FRE Original and FRE Adapted). Thus, a hypothesis was set to test the existence of significant differences of such measures, based on four categorical variables: gender, parenthood, program level and program stage,

$\mathrm{H}_{4}$ : There are no significant differences (at the .05 alpha level) between the EW-CTET, MSLQ$\mathrm{CT}$, and FRE (original and adapted) indicators considering (a) gender, (b) parenthood, (c) program level, and (d) program stage. 


\section{REVIEW OF THE LITERATURE}

The importance of critical reading and writing skills for accountants relates to more general skills required for success in accounting. Interaction with text in the form of critical reading and writing are important subsets of the communication skills targeted by business education research. A good example is the National Standards for Business Education Curriculum Model (NBEA, 2001) which includes communication as one of the eleven content areas of business education "...mastery of the oral and written skills essential for interacting effectively with people in the workplace and in society" (p. 36). Additional testimony for the relevance of communication skills in the accounting profession was registered by the Accounting Education Change Commission (1990), while defining the desired skills for accountants, with one specifically related to communication: "communication skills include both receiving and transmitting information and concepts, including effective reading, listening, writing, and speaking" (p. 307).

The relevance of reading in accounting education is also stressed by Manninen (1997), while discussing aspects of critical reading of three different elements:

a) ontological argument,

b) epistemological argument, and c) numerical backup material. The idea is to help students "learn to read persuasive accounting texts critically" (Manninen, 1997 , p. 281). Thus, it is not only a matter of being relevant, but also of being possible to intervene on this subject. Cox, Bobrowski, and Maher (2003) noted the effectiveness of improving abstract writing combined with adopting a particular method of critical thinking among business students including accounting students. Stone and Shelley (1997) conducted a study within the accounting undergraduate program at the University of Illinois at Urbana-Champaign, based on a particular instructional method (PD - Project Discovery), which emphasizes "acquiring intellectual skills and improving attitudes" (p. 35), reaching positive conclusions. In a similar path, Springer and Borthick (2004) also explore formal intervention to help accounting students improve critical thinking, or to shift "from knowing to thinking" (p. 278). These are specific examples of the existing concern in terms of both a) instructional improvements, and b) organizations' demands in relation to enhancing business students' critical thinking skills while interacting with text. Given the necessity of critical interaction, the question then becomes one of assessing that critical interaction.

One method of evaluating the relative quality of written materials is to apply a readability formula. Readability is a multifaceted construct dependent upon text properties, reader characteristics, and their interactions (Bailin \& Grafstein, 2001). These formulae provide a 


\section{repc}

simplistic, yet useful quantitative assessment of the degree of difficult or unfamiliar words and the relative presence of complicated grammatical structures (Bailin \& Grafstein, 2001). Readability is defined as ease of reading coupled with clear expressions of ideas and emotions. A readability formula provides a sense of knowing the level of difficulty of a text passage (Bailin \& Grafstein, 2001).

According to Gunning (2003), readability fosters the appropriate connection of students and materials. Critical thinking serves as the vehicle for interaction from text to learner and from learner to others through written output, but readability is the bridge for interaction assuring an appropriate, moderately challenging level of interaction. That connection is reminiscent of Vygotsky's (1978) zone of proximal development where learning occurs beyond the limits of normal capability but within the realm of possibility. The student interactions must strike a balance between the boredom of too little challenge and the frustration and surrender of too much challenge. Therefore it is important to match the complex interactions of text and reader, or writer, in terms of text, task, reader, and strategy variables (Meyer, 2003). This balanced interaction, in turn, fosters improved interactions with text input or output and an opportunity for the application of critical thinking.

Thinking may be viewed in terms of general or specific faculties. Perry (1970) described intellectual and moral growth in terms of levels and stages. The lower part of the scale could be said to represent the thought processes of novices or those new to a particular domain (e.g., accounting) and represents information in what Perry called a dualistic pattern. The dualistic view is that questions of truth are represented in a dichotomy (e.g., right/wrong, good/bad, or yes/no) and that the expert (text) has the right answer. As critical thinking skills progress, students learn to connect through writing and with text in new ways both to express themselves and to evaluate the information more critically instead of merely memorizing information from experts and repackaging the ideas for others. Regardless of whether the desired outcome is a better understanding of text or creation of cogent written materials, critical thinking consists of certain skills and strategies, and dispositions to perform them. Critical thinking activities connected with reading might include the objective evaluation of statements according to rules of logic or, as described by Ennis (1989), "reasonable reflective thinking focused on deciding what to believe or do" (p. 4). The same goals would apply when building and supporting a case while writing. By looking at the reverse side of the coin, which is critical reading, the relationship of critical thinking and writing can more readily be seen. The goal of critical reading is to enhance learning through the application of knowledge related to logical and rhetorical skills. It is a process of evaluating whether the text relies upon assumptions and opinions by making judgements about the quality of textual arguments and searching for organizational patterns, deep structures, and types of reasoning along with the quality of the evidentiary support. 


\section{RESEARCH DESIGN}

Due to the nature of the topic involved in this study, this research has an exploratory design. The evidence from these findings can support discussions on this problem, but are not aimed at causality. A correlational design was chosen to test the relationships among predictor variables and the criterion variables of critical thinking in reading and writing among accounting students. The function of a correlational study is to investigate whether hypothetical, non-causal relationships actually exist and to report both direction and strength of that relationship. Also, an ANOVA procedure was used to check the existence of significant differences between the criterion variables while considering a set of predictor variables (categorical) of particular interest.

This study relied on a direct measurement approach (Rea \& Parker, 1997). A set of techniques to collect, record, compile and analyze data was used to support the quantitative interpretation of facts. The literature review supported the analysis giving foundation for this discussion.

The most relevant type of data collected here is related to human perception and response in terms of subjective matters like critical thinking. It is relevant to state that, according to Creswell (2003, p. 7), "we cannot be positive about our claims of knowledge when studying the behavior and actions of humans," and this remark is important even considering the widely known and valid instruments used in this study.

\section{INSTRUMENTATION}

Three previously validated instruments were used in this study. The first instrument was the Motivated Strategies for Learning Questionnaire (MSLQ-CT). The MSLQ instrument was developed at the National Center for Research to Improve Postsecondary Teaching and Learning (University of Michigan), and according to the Manual for the Use of the Motivated Strategies for Learning Questionnaire (Pintrich; Smith; Garcia \& McKeachie, 1991, p. 3), the MSLQ instrument is "designed to assess college students' motivational orientations and their use of different learning strategies for a college course." The MSLQ started to be developed informally in 1982, supported by a general theoretical framework based on research conducted by the authors, and began formally in 1986, when the NCRIPTAL was founded at the University of Michigan (Pintrich; Smith; Garcia \& McKeachie, 1991, p.3). Consisting of 81 items, the instrument has two parts grouping the main variables: Motivation (6 variables) and Learning Strategies (9 variables). In this paper, we used just one variable (critical thinking) from the Cognitive and Metacognitive Strategies subscale (part of Learning Strategies). The MSLQ scales were successfully tested (Pintrich; Smith; Garcia \& McKeachie, 1991, p. 79) for factor validity via two confir- 


\section{repec}

matory analyses: (a) motivation items and (b) cognitive and metacognitive strategy (where the critical thinking variable is found). The analyses were developed based on a sample of 380 students (only seven of them were graduate students).

The second instrument was the Ennis-Weir Critical Thinking Essay Test (EW-CTET). This test requires students to formulate a response to a fictitious letter to the editor of an also fictitious newspaper following the detailed instructions on the instrument. The answer must consist of nine paragraphs and the EW-CTET manual provides clear scoring criteria for each paragraph. Several tests were conducted in order to evaluate validity (Ennis \& Weir, 1985, p. 3) with the results showing content validity and by 1985 initial stages of construct validity. During 1998, the reliability and construct validity of the instrument were ranked, respectively as "good" and "moderate" by the author, who stated that it "...has strengthened somewhat over the years" (Ennis, 1998, p. 3).

Readability formulae rely upon sentence length and either the average number of syllables or the presence of words on pre-defined lists of known words. Gunning (2003) cites Zipf's Law which connects word length with frequency and frequency with familiarity and therefore understanding. Formulae provide a practical method for estimating readability on semantic and syntactic measures (Meyer, 2003).

The third instrument used was the Flesch Reading Ease (FRE). The FRE scale ranges from zero (most difficult) to 100 (very easy) with a "standard" score between 60 and 70 . Rudolf Flesch (1949) commented that his formula was more of a rough estimate than a magic formula for good writing. However, his formula still provides a simplistic but useful quantitative method for comparing writing and is incorporated (Flesch-Kincaid) in word processing programs such as Microsoft Word ${ }^{\oplus}$ to help people assess their own writing.

The original FRE formula is: Score $=206.835-(1.015 \times \mathrm{ASL})-(84.6 \times \mathrm{ASW})$ With:

$\mathrm{ASL}=$ average sentence length (number of words divided by the number of sentences)

ASW = average number of syllables per word (the number of syllables divided by the number of words).

All original instruments and research materials were translated into Brazilian Portuguese.

\section{SAMPLE AND DATA COLLECTION}

The study involved a sample of 65 undergraduate and graduate accounting students from the University of Sao Paulo (USP, Brazil), School of Economics, Business and Accounting. The students were enrolled during the last semester of 2004 and included those in both the early portion and late portion of their respective programs.

Data were used for correlation evaluation and the collection procedure involved in- 
tact groups with no control group. Collection of the data occurred in one session which took place in the normal classroom setting. The students received a description of the project and were informed of their rights to choose not to participate or to withdraw at any time and were then asked to give their consent by signing the written consent form. No participant names were recorded on the collected instruments and the forms were destroyed after the data were recorded in a database for statistical processing. Non-participants received study materials related to critical reading and writing. The materials were also given to the participants at the completion of the assessment.

The participants received two instruments, which were coded together by a random number, and no names were placed on the instruments, so it is impossible to identify the participants from the instruments. Upon entry of the results into a database, the instruments were destroyed. The MSLQ-CT questions took no longer than five minutes and the EWCTET was limited to forty minutes total. Ten minutes were allotted for reading the letter, and thirty minutes were allotted for writing a critical response.

After the students completed the instruments, their essay tests were scored according to the Ennis-Weir Manual, and feedback (showing points for each paragraph and the criteria for the points) was provided based on the random coding. In addition students were given further information on critical reading and writing to help improve their skills.

All handwritten forms were typed into Microsoft Word ${ }^{\odot}$ document files so that each answer was recorded electronically. These responses were submitted to the traditional FRE scoring procedure and the results were added to the data file for later analysis. Next the responses were transferred to a Brazilian word-processing program called Redator ${ }^{\odot}$ which includes an adapted version of FRE (Brazilian Portuguese) developed by the University of Sao Paulo at Sao Carlos. FRE scores consistent with Brazilian Portuguese were obtained and added to the data file.

\section{DATA ANALYSIS}

\section{Dataset}

After eliminating student data with missing information, a total of 64 datasets were deemed useable. According to the demographic information provided by the students the research group had a mean age of 27.75 years. A total of $59.4 \%$ of the participants were males, $87.5 \%$ had no children, $65.6 \%$ were enrolled in the undergraduate program, and $68.8 \%$ of the students were in the last half of their program.

The data collected from the two instruments were placed into a Microsoft Excel ${ }^{\odot}$ spreadsheet that was divided into these variables groups: $Q_{1}$ to $Q_{6}$ (participant info), $Q_{7 a}$ to $Q_{7 e}(M S L Q-C T), E_{1}$ to $E_{7}$ (essay details: characters, words, sentences, para- 
graphs, and correspondent ratios), and $\mathrm{E}_{8}$ to $\mathrm{E}_{11}$ (criterion variables: FRE, EW-CTET, MSLQ-CT, and FRE-BR).

The descriptives of the four main indicators are shown in Table 1. It is possible to observe that the original FRE indicator, when compared to the Brazilian FRE indicator, bears a higher average and a higher standard deviation. In a scale ranging from 0 to 100 (the higher the indicator, the easier the reading), the FRE mean for this sample was $55.5(S D=9.289)$ and the Brazilian FRE mean was $48.5(S D=9.123)$.

Table 1: Main Indicators - Descriptives

\begin{tabular}{|c|c|c|c|c|c|c|c|c|c|}
\hline Mean & & 55,50 & 15,16 & 26,84 & 48,50 & 1,161 & ,511 & ,543 & 1,140 \\
\hline \multirow{2}{*}{$\begin{array}{l}95 \% \text { Confidence } \\
\text { Interval for Mean }\end{array}$} & Lower Bound & 53,18 & 14,14 & 25,76 & 46,22 & & & & \\
\hline & Upper Bound & 57,82 & 16,18 & 27,93 & 50,78 & & & & \\
\hline $5 \%$ Trimmed Mean & & 55,69 & 15,28 & 26,95 & 48,61 & & & & \\
\hline Median & & 56,50 & 15,00 & 27,00 & 49,50 & & & & \\
\hline Variance & & 86,286 & 16,705 & 18,864 & 83,238 & & & & \\
\hline Std. Deviation & & 9,289 & 4,087 & 4,343 & 9,123 & & & & \\
\hline Minimum & & 32 & 5 & 15 & 29 & & & & \\
\hline Maximum & & 76 & 23 & 35 & 66 & & & & \\
\hline Range & & 44 & 18 & 20 & 37 & & & & \\
\hline Interquartile Range & & 10,75 & 5,00 & 5,00 & 14,50 & & & & \\
\hline Skewness & &,- 386 &,- 303 &,- 409 &,- 173 & 299 & 299 & 299 & 299 \\
\hline Kurtosis & &, 237 &,- 035 & 057 &,- 768 & .590 & .590 & .590 &, 590 \\
\hline
\end{tabular}

From Table 1, we observe that the EW-CTET mean was 15.16 (SD = 4.087), considering that the test admits scores ranging from -9 to +29 , according to its explicit criteria. Using the Manual Supplement for the Ennis-Weir Critical Thinking Essay Test (1998) as a basis for comparison, we found that this study's mean was higher. It is important to remember that graduate students were included in this study and the two particular groups from the EW-CTET Manual Supplement used in this comparison are both based on undergraduate responses: a) Group A, freshmen, midsize midwest US university, and b) Group F, undergraduates at a large midwestern US university.

Table 2: EWCT-ET - Comparison

\begin{tabular}{cccc}
\hline & $\mathbf{N}$ & Mean & Std.Dev. \\
\hline \hline Original Study & & & \\
\hline Group A & 1617 & 13.1 & 5.34 \\
\hline Group F & 187 & 14.3 & 6.14 \\
\hline & & & \\
\hline \hline This Study & & & \\
\hline Group - USP & 64 & 15.1 & 4.08 \\
\hline
\end{tabular}


The observed means for each paragraph of the EW-CTET were: 1.63 (paragraph 1), 1.71 (paragraph 2), 1.35 (paragraph 3), 1.37 (paragraph 4), 2.17 (paragraph 5), 2.06 (paragraph 6), 2.14 (paragraph 7), 0.17 (paragraph 8), and 2.57 (paragraph 9). In addition, the MSLQ-CT overall mean was $26.84(S D=4.343)$, considering a potential total of 35 points (five items, seven levels of choice). Observing the descriptives from the original MSLQ Learning Strategies Scales (Pintrich, Smith, Garcia, and McKeachie, 1991), we found lower numbers for the Critical Thinking subset, when compared to numbers found in this current study:

Table 3: MSLQ-Critical Thinking - Comparison

\begin{tabular}{|c|c|c|c|c|}
\hline & \multicolumn{2}{|c|}{ Original Study } & \multicolumn{2}{|c|}{ This Study (USP) } \\
\hline Item & Mean & Std.Dev. & Mean & Std.Dev.1 \\
\hline$\left(Q_{72}\right)$ & 3.83 & 1.77 & 5.53 & 1.17 \\
\hline $2\left(Q_{7 b}\right) 4.36$ & & 1.68 & 5.56 & \\
\hline $3\left(Q_{70}\right) 3.81$ & & 1.85 & 4.89 & \\
\hline $4\left(Q_{7 d}\right) 4.66$ & & 1.74 & 5.37 & \\
\hline $5\left(Q_{7 e}\right) 4.15$ & & 1.49 & 5.48 & \\
\hline Scale & 4.16 & 1.28 & 5.37 & 0.87 \\
\hline
\end{tabular}

It is noteworthy that item 5 of the MSLQ ("Whenever I read or hear an assertion or conclusion in this class, I think about possible alternatives"), in both cases, bears the lowest standard deviation. The lowest mean, in both cases, is present in item number 3 ("I treat the course material as a starting point and try to develop my own ideas about it"). Items bearing the highest mean are different between the original (item 4, "I try to play around with ideas of my own related to what I am learning in this course") and this study (item 2, "When a theory, interpretation, or conclusion is presented in class or in the readings, I try to decide if there is good supporting evidence").

\section{Preliminary Tests}

Analyzing the dataset, all four main indicators (dependent variables) bear distributions that may be considered good approximations to the normal distribution, considering the Kolmogorov-Smirnov test of normality at the .05 alpha level. Similar results were obtained with the Shapiro-Wilk test. This is a consideration of major relevance, supporting the use of parametric statistical procedures while analyzing data. 
Table 4: Main Indicators - Tests of Normality

\begin{tabular}{lllllll}
\hline \hline & \multicolumn{7}{c}{$a$} \\
\cline { 2 - 7 } &, 088 & 64 &, $200^{*}$ &, 979 & 64 &, 344 \\
\hline FRE &, 080 & 64 &, $200^{*}$ &, 971 & 64 &, 139 \\
EWCTET &, 101 & 64 &, 169 &, 978 & 64 &, 322 \\
MSLQCT &, 092 & 64 &, $200^{*}$ &, 978 & 64 &, 298 \\
FRE BR & & & & & & \\
\hline \hline
\end{tabular}

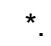

a.

\section{Correlations}

Part of this study deals with the idea of connections between reading and writing in light of critical thinking. In this sense, we tested the existence of correlations (at the .05 alpha level) among the main indicators present here: MSLQ-CT, EW-CTET, FRE, and FRE-BR. The idea is to observe if significant linear correlations (Pearson) are present among these indicators obtained from the sample: written materials and multiple-choice questions (MSLQ-CT). After obtaining the correlation matrix (Table 5), it is possible to observe a strong, significant positive correlation $(0.899)$ between the two versions (original and adapted - Brazilian Portuguese) of the Flesch Reading Ease indicator (FRE).

\section{Table 5: Main Indicators - Correlations}

\begin{tabular}{cllll}
\hline \hline & & & & \\
\hline EWCTET & Pearson Correlation &,$- 259^{*}$ & & \\
& Sig. (2-tailed) &, 039 &, & \\
\hline MSLQCT & Pearson Correlation &,- 137 &,- 084 & \\
& Sig. (2-tailed) &, 279 &, 507 & \\
\hline FRE_BR & Pearson Correlation &, $899^{* *}$ &,$- 332^{* *}$ &,- 104 \\
& Sig. (2-tailed) &, 000 &, 007 &, 413 \\
\hline \hline$*$ & & & & \\
$* *$ & & & &
\end{tabular}

When analyzing the data for correlations among the four main indicators (criterion variables), there were no significant correlations with the MSLQ-CT indicator. In contrast, the EW-CTET indicator presented significant negative correlations with the FRE indicators (original and adapted) as shown. This is to say that the higher the EW-CTET grade, the lower the FRE level (meaning a text with a more difficult reading level). 
Analyzing the correlations among the four main indicators and writing details (number of characters, words, sentences, and paragraphs), it was possible to find additional interesting correlations. The MSLQ-CT indicator does not present correlations with writing details, but the EW-CTET presents significant correlations with characters, words, and paragraphs (Table 6). Both original and adapted FRE indicators present significant negative correlations with the number of characters and words. So, according to Table 6 , the higher the FRE indicator (easier reading), the lower the number of characters and words.

Table 6: Main Indicators and Writing Details - Correlations

\begin{tabular}{|c|c|c|c|c|c|c|c|c|c|}
\hline \multirow[t]{2}{*}{ Characters } & Pearson Correlation &,$- 455^{\star \star}$ & ,330** & 130 &,$- 543^{\star \star}$ & 1 & & & \\
\hline & Sig. (2-tailed) &, 000 & ,008 & ,305 &, 000 & , & & & \\
\hline Words & Sig. (2-tailed) & ,002 & ,009 & ,405 &, 000 &, 000 & , & & \\
\hline Sentences & Pearson Correlation & ,172 & ,085 & ,054 & ,056 &, $633^{* *}$ &, $626^{* *}$ & 1 & \\
\hline Paragraphs & Sig. (2-tailed) & 412 & .006 & 386 & 249 & 025 & .028 & .025 & \\
\hline
\end{tabular}

*.

Still analyzing correlations, it is interesting to observe that no significant correlations were found between the main indicators and students' age (Table 7). Thus, based on this sample, the ability to write easy-to-read text is not related to age.

Table 7: Main Indicators and Age - Correlations

\begin{tabular}{llrrrr}
\hline \hline & & & & \\
\hline Age & Pearson Correlation &,- 041 &, 163 &, 210 &,- 040 \\
& Sig. (2-tailed) &, 747 &, 197 &, 095 &, 752 \\
\hline \hline
\end{tabular}

\section{Comparison of Means}

In addition to the correlational analysis, the four main indicators (criterion variables) were exposed to tests of comparison of means (ANOVA), in terms of the predictor variables (at the .05 alpha level). The first test looked for differences in the four main indicators with gender as the predictor variable (this sample had $59.4 \%$ of males). Data passed the Levene test of homogeneity of variances (Table 8 ) and the results showed no significant differences between male and female students (Table 9). 
Table 8: Main Indicators - Gender

Homogeneity of Variances

\begin{tabular}{lcccc}
\hline \hline & & & & \\
& Levene & & & \\
\hline FRE &, 047 & 1 & 62 &, 828 \\
EWCTET &, 815 & 1 & 62 &, 370 \\
MSLQCT &, 165 & 1 & 62 &, 686 \\
FRE BR & 1,828 & 1 & 62 &, 181 \\
\hline \hline
\end{tabular}

Table 9: Main Indicators - Gender - ANOVA

\begin{tabular}{|c|c|c|c|c|c|c|}
\hline & & Sum of & & & & \\
\hline \multirow[t]{3}{*}{ FRE } & Between Groups & 12,696 & 1 & 12,696 & , 145 & ,705 \\
\hline & Within Groups & 5423,304 & ๔2 & 87,473 & & \\
\hline & Total & 5436,000 & ๓3 & & & \\
\hline \multirow[t]{3}{*}{ EWCTET } & Between Groups & 6,559 & 1 & 6,559 & ,389 &, 535 \\
\hline & Within Groups & 1045,879 & ๔2 & 16,869 & & \\
\hline & Total & 1052,438 & ๓3 & & & \\
\hline \multirow[t]{3}{*}{ MSLQCT } & Between Groups & 3,118 & 1 & 3,118 & , 163 & ,688 \\
\hline & Within Groups & 1185,320 & 62 & 19,118 & & \\
\hline & Total & 1188,438 & ๔3 & & & \\
\hline \multirow[t]{3}{*}{ FRE_BR } & Between Groups & 88,680 & 1 & 88,680 & 1,067 & ,306 \\
\hline & Within Groups & 5155,320 & ๔2 & 83,150 & & \\
\hline & Total & 5244,000 & $\mathfrak{3}$ & & & \\
\hline
\end{tabular}

Thus, gender did not play a significant role, based on this sample, in terms of critical thinking. These results are reinforced by other robust tests of equality of means (Welch and Brown-Forsythe).

In addition, comparisons were made between groups of students with and without children (the sample had only $12.5 \%$ of the participants with children). Again, the data passed the Levene test of homogeneity of variances (Table 10), and the results showed no significant differences between students with and without children (Table 11).

Table 10: Main Indicators - Parenthood Homogeneity of Variances

\begin{tabular}{lcccc}
\hline \hline & & & & \\
& Levene & & & \\
\hline FRE &, 418 & 1 & 62 &, 520 \\
EWCTET &, 051 & 1 & 62 &, 822 \\
MSLQCT &, 187 & 1 & 62 &, 667 \\
FRE BR &, 344 & 1 & 62 &, 560 \\
\hline \hline
\end{tabular}


Table 11: Main Indicators - Parenthood - ANOVA

\begin{tabular}{|c|c|c|c|c|c|c|}
\hline & & Sum of & & & & \\
\hline \multirow[t]{3}{*}{ FRE } & Between Groups & 32,143 & 1 & 32,143 & ,369 & ,546 \\
\hline & Within Groups & 5403,857 & 62 & 87,159 & & \\
\hline & Total & 5436,000 & ๔ & & & \\
\hline \multirow[t]{3}{*}{ EWCTET } & Between Groups & 61,509 & 1 & 61,509 & 3,848 & ,054 \\
\hline & Within Groups & 990,929 & 62 & 15,983 & & \\
\hline & Total & 1052,437 & ๓3 & & & \\
\hline \multirow[t]{3}{*}{ MSLQCT } & Between Groups & 29,009 & 1 & 29,009 & 1,551 & ,218 \\
\hline & Within Groups & 1159,429 & 62 & 18,700 & & \\
\hline & Total & 1188,437 & ๔3 & & & \\
\hline \multirow[t]{3}{*}{ FRE_BR } & Between Groups & 69,143 & 1 & 69,143 & ,828 & ,366 \\
\hline & Within Groups & 5174,857 & 62 & 83,465 & & \\
\hline & Total & 5244,000 & 6 & & & \\
\hline
\end{tabular}

No effect was found in this study that connected parenthood to critical thinking and writing indicators. These results are also reinforced by other robust tests of equality of means (Welch and Brown-Forsythe).

Moreover, groups of students at different stages of their program (beginning or end) were compared. Again, the data passed the Levene test of homogeneity of variances (Table 12), and the results presented no significant differences between these groups of students (according to program stage). Based on this sample, critical thinking and writing indicators are not different for students at the beginning or end of their program. Other robust tests of equality of means (Welch and Brown-Forsythe) reinforced these results.

\section{Table 12: Main Indicators - Program Stage} Homogeneity of Variances

\begin{tabular}{lrlll}
\hline \hline & & & & \\
& Levene & & & \\
\hline FRE & 2,210 & 1 & 6 &, 142 \\
EWCTET &, 048 & 1 & 62 &, 827 \\
MSLQCT & 1,568 & 1 & 62 &, 215 \\
FRE BR &, 643 & 1 & 62 &, 426 \\
\hline \hline
\end{tabular}


Table 13: Main Indicators - Program Stage - ANOVA

\begin{tabular}{|c|c|c|c|c|c|c|}
\hline & & Sum of & & & & \\
\hline \multirow[t]{3}{*}{ FRE } & Between Groups & 3,564 & 1 & 3,564 & ,041 & ,841 \\
\hline & Within Groups & 5432,436 & ๔ & 87,620 & & \\
\hline & Total & 5436,000 & ๓3 & & & \\
\hline \multirow[t]{3}{*}{ EWCTET } & Between Groups & 16,092 & 1 & 16,092 & ,963 & ,330 \\
\hline & Within Groups & 1036,345 & 62 & 16,715 & & \\
\hline & Total & 1052,438 & ๔3 & & & \\
\hline \multirow[t]{3}{*}{ MSLQCT } & Between Groups & ,256 & 1 & ,256 & ,013 & ,908 \\
\hline & Within Groups & 1188,182 & ๔ & 19,164 & & \\
\hline & Total & 1188,437 & ๓3 & & & \\
\hline \multirow[t]{3}{*}{ FRE_BR } & Between Groups & 32,073 & 1 & 32,073 & ,382 & ,539 \\
\hline & Within Groups & 5211,927 & 6 & 84,063 & & \\
\hline & Total & 5244,000 & 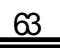 & & & \\
\hline
\end{tabular}

Indicators among groups of students were also compared according to their program level (undergraduate, master, and doctorate). Again, the data passed the Levene test of homogeneity of variances (Table 14), and the results presented no significant differences among these groups of students: according to program level (Table 15). Based on these results, critical thinking and writing indicators are not different according to program level (undergraduate, master, or doctorate). Other robust tests of equality of means (Welch and Brown-Forsythe) reinforced these results.

\section{Table 14: Main Indicators - Program Level Homogeneity of Variances}

\begin{tabular}{lrrrr}
\hline \hline & & & & \\
\hline FRE &, 220 & 2 & 61 &, 803 \\
EWCTET &, 127 & 2 & 61 &, 881 \\
MSLQCT &, 500 & 2 & 61 &, 609 \\
FRE BR & 1,512 & 2 & 61 &, 229 \\
\hline \hline
\end{tabular}


Table 15: Main Indicators - Program Level - ANOVA

\begin{tabular}{|c|c|c|c|c|c|c|}
\hline & & Sum of & & & & \\
\hline \multirow[t]{3}{*}{ FRE } & Between Groups & 29,531 & 2 & 14,765 & ,167 & ,847 \\
\hline & Within Groups & 5406,469 & 61 & 88,631 & & \\
\hline & Total & 5436,000 & ๒ & & & \\
\hline \multirow[t]{3}{*}{ EWCTET } & Between Groups & 13,922 & 2 & 6,961 & ,409 & ,666 \\
\hline & Within Groups & 1038,516 & 61 & 17,025 & & \\
\hline & Total & 1052,438 & ๒ & & & \\
\hline \multirow[t]{3}{*}{ MSLQCT } & Between Groups & 35,468 & 2 & 17,734 & ,938 & ,397 \\
\hline & Within Groups & 1152,969 & 61 & 18,901 & & \\
\hline & Total & 1188,437 & ๒ & & & \\
\hline \multirow[t]{3}{*}{ FRE_BR } & Between Groups & 15,870 & 2 & 7,935 & ,093 & ,912 \\
\hline & Within Groups & 5228,130 & 61 & 85,707 & & \\
\hline & Total & 5244,000 & $\mathfrak{6}$ & & & \\
\hline
\end{tabular}

\section{RESULTS}

Based on the evidence gathered in this study in terms of accounting students' critical reading and writing skills, supported by widely-known instruments (MSLQ, EW-CTET, original and adapted FRE), we register the following findings and conclusions in the light of the stated hypotheses.

$\mathbf{H}_{1}$ : The critical thinking levels of accounting students, based on participants of this study, are equal to those of MSLQ-CT and EW-CTET original studies.

The critical thinking levels of accounting students at USP were slightly higher than those observed in both the original studies. This may have occurred due to the fact that this sample involved undergraduate and graduate students, while in both original studies the sample consisted of undergraduates only. The EW-CTET average score observed in this study was 15.1, just above the 14.3 found among 187 undergraduate students at a large midwestern U.S. university. In addition, the original MSLQ-CT scale mean was 4.16 (SD= 1.28), a little bit lower than the mean found in this study: 5.37 ( $S D=0.87$ ). Here, we must state that among the 380 respondents of the original MSLQ study, only nine were economics majors (no business or accounting majors), bearing a dramatic difference when compared to this sample. From this we may conclude that there are special factors acting toward these findings, and three of them deserve particular attention: a) time frame (e.g., EW-CTET original study was developed 20 years ago, b) discipline context (e.g., business area), and c) conditions of learning based on the social environment (e.g., evening courses, work experience). Students exposed to such situations may develop critical thinking skills through dis- 


\section{repec}

tinct paths when compared to students of the original studies (e.g., EW-CTET and MSLQ). It is clear from our findings that this particular concern requires further investigation.

$\mathbf{H}_{2}$ : The writing quality levels of accounting students, based on participants of this study, are equal to the suggested FRE plain text score minimums (original and adapted).

The writing quality levels observed from this sample are just below the "plain text minimum" (60 points), meaning texts with more difficult reading. According to the FRE study, "the minimum score for plain English is 60, or about 20 words per sentence and 11/2 syllables per word." In this paper we found average scores of 55.5 (original FRE) and 48.5 (adapted FRE - Brazilian Portuguese). These averages represent texts that are slightly more difficult than the so called "plain text" (perhaps due to the inclusion of a greater number of graduate students), in terms of the Flesch Reading Ease indicator, but it is also important to stress that the adapted FRE (Brazilian Portuguese) falls within the "college" school level range for text writing (from 30 to 50).

Based on these findings, we conclude on two relevant issues: a) the adapted FRE, and b) language of postsecondary students. First, through this study we experienced that different languages (e.g., Brazilian Portuguese) claims for FRE formulae adjustments in order to provide a more accurate representation of relations with parameters like number of words and syllables which are directly related to the particular language scheme or framework. In addition, we conclude that postsecondary students are able to use language as persuasive means, while developing arguments to react to an idea or issue, tending to write text with a higher level of complexity (e.g., grammatically and syntactically).

$\mathbf{H}_{3}$ : There are significant correlations (at the .05 alpha level) between MSLQ-CT, EW-CTET and FRE (original and adapted) scores for accounting students, based on participants of this study.

No significant correlations were found with the MSLQ-CT indicator. A significant positive correlation $(+0.899)$ was found between original and adapted FRE indicators. While analyzing the EW-CTET, two significant negative correlations were found with both original $(-0.259)$ and adapted (-0.332) FRE.

We also found that the MSLQ-CT indicator does not present correlations with writing details, but the EW-CTET presents significant positive correlations with number of characters, words, and paragraphs. Additionally, both original and adapted FRE indicators present significant negative correlations with the number of characters and words as would be expected from the formula. No significant correlations were found in terms of students' age and these four indicators (MSLQ-CT, EW-CTET, FRE, and FRE-BR).

The conclusions, in this case, are related to the essence of the MSLQ instrument, much different in terms of its own approach, when compared to the EW-CTET. The fact that no significant correlations were found with MSLQ-CT suggests that its multiplechoice approach, in order to assess critical thinking, is very basic. This approach is 
very well integrated and consistent when we analyze the whole MSLQ instrument, but when used in an isolated way it bears a limited discriminating effectiveness. Its value relies on approaching critical thinking through an indirect way. On the other hand, the correlations found in terms of the EW-CTET reveals, to a great extent, that experiencing (direct way) a critical thinking activity is a more effective approach when registering students' critical thinking skills.

$\mathbf{H}_{4}$ : There are no significant differences (at the .05 alpha level) between the EW-CTET, MSLQ$\mathrm{CT}$, and FRE (original and adapted) indicators considering (a) gender, (b) parenthood, (c) program level, and (d) program stage.

No significant differences were found while comparing the four main indicators and the selected subsets (gender, parenthood, program level - undergraduate/graduate, and program stage), using ANOVA procedures. This is to say that none of these parameters influenced the observed levels of critical reading and writing for this sample.

\section{CULTURAL ASPECTS}

Since early stages of this study, the challenge of using the selected instruments (Ennis-Weir and MSLQ) with these participants was obvious, due to their original purposes and intrinsic differences (e.g., techniques), but also, in terms of applying them in a different cultural setting (e.g., Brazil). The selected instruments were developed in different moments in time (Ennis-Weir, 1985 and MSLQ, 1991), with different approaches in terms of Critical Thinking (e.g., narrow/wide), techniques (e.g., essay/Likert-scale), and original sample (size, profile, disciplines etc.). During the conduct of this study, we faced the fact that both Ennis-Weir theory and instrument bring a particular approach to authority and respect that was not smoothly observed within this sample.

The interesting issue that we found here is related to one particular paragraph from EW-CTET: paragraph eight. As mentioned before, in a scale ranging from -1 to +3 the sample mean was very low: 0.17 (with several "penalizing scores": -1). Analyzing this particular paragraph, its original underlying idea, and the suggested scoring criteria, we may observe that it is considered "one of the best arguments in the letter" (Ennis \& Weir, 1985). This mentioned paragraph exposes the idea of two authorities in the subject in discussion (e.g., Director of the National Traffic Safety Council and National Association of Police Chiefs) supporting the main argument of the letter (the basis of the test).

In this sense, the EW-CTET manual clearly states that while scoring this paragraph the student is expected to recognize that the paragraph is ok. In addition, the manual indicates that the author of the letter "... is not required to give evidence that the authorities actually said what he claims they have said, or to produce the reasons they gave for making 


\section{repec}

their recommendations. Respondents who criticize him for not doing either of these things should be faulted for bad judgment in justifying" (Ennis \& Weir, 1985, p. 9).

Most of the students from this sample engaged in this path of reaction (with minor deviations): the fact that an authority is saying something, does not grant the right of not supporting the idea (which is intended to be penalized by the scoring procedure). This would appear to be more a culturally related dimension similar to Hofstede's (1983) power distance, or unquestioning respect for authority figures, than a dimension of critical thinking. Here, we have a cultural aspect that should be explored in depth, with the required scientific approach (another study) to understand if this fact occurred by chance or not.

\section{CONCLUSION}

Business education, as in other disciplines, bears a need for improving its instructional methods. A major step in this direction is the needs assessment of particular educational objectives. Like those related to communication skill, in order to support students' readiness to act both academically and professionally. Such skills play a relevant role in professional life especially in the business field, as remarked by several organizations (AAA, 1953, p. 53, AECC, 1990, p. 307, AICPA, 2002, p. 11, NBEA, 2001, p. 36). Thus, a first note, as a conclusion of this paper, must be registered here. The majority of the subjects of this sample, the students in both levels (undergraduate and graduate), demonstrated great excitement while participating in this study. This supplemental contribution of this paper highlights that students are concerned about critical thinking, and they can relate it to their professional lives, as well as to the job-market expectations.

Linked to that, institutions, as providers of the formal educational environment discussed here, may profit from this type of discussion on critical thinking, as a way of supporting their planning, putting more power in supporting communication and reasoning skills. In other words, it is expected that this kind of achievement (improving communication and reasoning skills) does not happen by chance.

This study provides conditions to discuss critical thinking within the educational environment, focusing on accounting students. Assuming the educational institutions as key providers expected to intervene in students' development, these findings suggests a deep reflection on how educators would behave as agents of change in the reported scenario. Such reflection is ignited by the two main dimensions explored in this study: critical thinking (MSLQ-CT and Ennis-Weir CT-ET), and communication (Flesch Reading Ease). Thus, more than assessing the sample using such indicators, this study brings contributions, based on these findings, aimed at appropriate interventions capable of helping students' metacognitive skill development, and both academic and professional performance.

The utility of assessing the development level of learners is minimal unless it can be 
aligned with a system for improving their performance. Exhibit 1 shows the development levels related to the Kitchener and King stages (1981) of reflective judgment. It should be noted that people can be at different levels in relation to different contexts. (e.g., while you might be at stage four in your field, you initially drop to level two when you begin to learn a new language). As with other types of learning, the process for helping someone move through the stages would consist of modeling the desired practices, scaffolding the learner to perform the practice, and then observing and assessing the unaided performance.

\section{Exhibit 1: A Hierarchy of Reflective Judgement}

Knowledge results from reasoned, probabilistic inquiry
Knowledge is applied across contexts to solve ill-structured problems
Knowledge is contextual and evidence must be interpreted subjectively
Knowledge is uncertain, must be supported by reason and evidence
Absolute knowledge exists, but if unknown observation and judgment suffice
Knowledge is observed or given by authority
Sensory observed knowledge and judgments are absolute

The stages are key elements in analyzing and acting on the learning process. Kitchener et al. conclude on the sequence of the stages remaining constant even considering differences in developmental function for reflective judgment, depending on how it is assessed: "people show higher levels of competence in reflective judgment after practice and even higher levels when there is contextual support during the assessment" (Kitchener et al., 1993, p. 905).

King and Kitchener (1994) consider the first two stages to be pre-reflective so the journey to reflective judgment begins at stage two. In order to move the student from stage two to stage three they need to begin to see conflict between two experts so a presentation of conflicting theories along with a discussion of the opposing views and the arguments provided by the experts will establish an awareness, which is the beginning of change. For instance, opposing arguments on full costing and variable costing from two experts can ignite the awareness on using different approaches or theories to provide the information required by different users.

Moving beyond stage three requires an understanding of evidence. Here different points of view must be supported by evidence. One way to accomplish this understanding 
is through the use of a case study where development of an alternative perspective can be based on evidence or, for a problem-based learning approach, let the students identify the evidence. This would be an excellent point to model the process for choosing among alternatives on the basis of applicability while explaining the decision process. An example of this in the same area mentioned before (cost accounting) would involve presenting data on the consequences of using full costing and variable costing in specific situations and having students ponder the evidence.

To get to stage five requires a proficiency in evaluation of competing arguments. This would be another great spot for case studies. It is important to highlight how different interpretations of factors within an argument may arise legitimately. Therefore it is important to evaluate arguments and interpretations both within and between competing positions. The example now (cost accounting) would include more than data on consequences, but also, interpretation from experts in the field, and these elements would serve as a basis for the student's own evaluation.

At stage five is the opportunity to illustrate that there are legitimate alternative paths to analysis. One way to accomplish this is to have the students construct a case study with two or more teams addressing the same controversial issue. As they illustrate the situation with multiple perspectives they are asked to choose one and to identify how they made the selection. This provides an excellent segue to an explanation of scholarly inquiry illustrated by your current research topics. In the cost accounting example, the relativism present in stage five could be achieved with students designing and developing two alternative solutions (full costing and variable costing) for a particular situation while providing arguments based on key elements as theories, user needs (internal versus external needs), best practices, dataset, ethics, and regulations.

To move on to stage six requires that learners construct their own point of view, one that relies upon current context, knowledge, and practices to evolve. One exercise is to have them develop a concept map for a specific accounting course and to identify both the interrelationships and how it has evolved over time. The cost accounting example could involve students in a deep reflection on the factors affecting the decision of using one particular approach (e.g., full costing or variable costing) as a solution for a given situation, while demanding personal arguments expressing student's own point of view.

Stage seven is related to the condition of constructing knowledge. To move on to stage seven learners must be able to evaluate and identify limitations on the current set of knowledge, while proposing a new way to solve an existing problem, with better outcomes. An example related to stage seven, and dealing with the cost accounting area, would involve learners in a situation where both full costing and variable costing would not generate the appropriate level of information required by a particular user, based on their decision model. The students would have to evaluate and ponder the limitations of existing methods, given 
this particular situation, and create a new way to solve the problem and generate the appropriate information as needed by the user.

The findings present in this study reinforce the idea that critical thinking among students of a particular field (e.g. accounting), bearing similar conditions of learning (e.g. working students, attending evening courses, etc.) within the same social environment, and with comparable life experiences are supposed to have consistent levels of critical thinking and communications skills. So, further analysis on these particular parameters should be conducted to explore, in depth, the existence of such influences or relationships. Beyond tackling these research questions, it is important to stress via this study that the concern about critical thinking, as well as reading and writing skills, is still a relevant issue. The advance in business education demands depth-and-breath research in several areas, and this one has its own space.

Ignited by supplemental findings of this study, further research aiming at cultural aspects of critical thinking, mainly within the business education area, is strongly recommended, essentially due to considering the continuing and spreading discussion on international business and accounting standards.

\section{ACKNOWLEDGEMENTS}

We would like to acknowledge the support of University of Illinois at Urbana-Champaign, USA and University of Sao Paulo, Brazil. In addition, we are thankful for the comprehension and support of Prof. Ennis while encouraging this study and providing the reasoning and instruments to accomplish this work. In this sense, we also register our thanks to University of Michigan, especially to the National Center for Research to Improve Postsecondary Teaching and Learning (NCRIPTAL) and the School of Education, for providing the MSLQ instrument and supporting theory. We also register our special thanks to the participant students, from the Department of Accounting and Actuarial Sciences (University of Sao Paulo).

\section{REFERENCES}

Accounting Education Change Commission - AECC (1990). Objectives of education or accountants: Position statement number one. Issues in Accounting Education, 5(2), pp. 307-312.

American Accounting Association - AAA (1953). Accounting teachers' guide (Urbana: Southwestern Publishing). 
American Institute of Certified Public Accountants - AICPA (2002). Information for uniform CPA examination candidates (New York: AICPA).

Bailin, A. and Grafstein, A. (2001). The linguistic assumptions underlying readability formulae: A critique. Language \& Communication, 21, pp. 285-301.

Baldwin, B. and Ingram, R. (1991). Rethinking the objectives and content of elementary accounting. Journal of Accounting Education, 9, pp. 1-14.

Baril, C., Wolcott, S., Bayes, P., Cunningham, B., Fordham, D., \& St. Pierre, K. (1999). Recommendations for the design of empirical studies examining curricular efforts to develop student critical thinking skills (New York: Federation of Schools of Accountancy).

Braun, N. M. (2004). Critical thinking in the business curriculum. Journal of Education for Business, 79(4), pp. 232-236.

Cox, P. L., Bobrowski, P. E., \& Maher, L. (1997). Teaching first-year business students to summarize: Abstract writing assessment. Business Communication Quarterly, 66(4), pp. 36-54.

Creswell, J. W. (2003). Research design: Qualitative, quantitative, and mixed methods approaches $\left(2^{\text {nd }}\right.$ ed.) (Thousand Oaks: Sage Publications).

Currie, G. and Knights, D. (2003). Reflecting on a critical pedagogy in MBA education. Management Learning, 34(1), pp. 27-49.

Ennis, R. H. (1989). Critical thinking and subject-specificity: Clarification and needed research. Educational Researcher, 18, pp. 4-10.

Ennis, R. and Weir, E. (1985). The Ennis-Weir Critical Thinking Essay Test (Pacific Grove, CA: Midwest Publications).

Ennis, R. (1998). Manual supplement for The Ennis-Weir Critical Thinking Essay Test. Retrieved February 10, 2005 from: http://faculty.ed.uiuc.edu/ rhennis/tewctet/info_about_ew_ test/Ewsupplnfo7_98.pdf

Ennis, R. (1998b). Is critical thinking culturally biased? Teaching Philosophy, 21(1), pp. 15-33. 
Flesch, R. (1949). The Art of Readable Writing (New York: Wiley).

Gracia, L. and Jenkins, E. (2002). An exploration of student failure on an undergraduate accounting programme of study. Accounting Education, 11(1), pp. 93-107.

Gunning, T. (2003). The role of readability in today's classroom. Topics in Language Disorders, 23(3), pp. 175-189.

Hofstede, G. (1983). Dimensions of national cultures in fifty countries and three regions, in: J. B. Deregowski, S. Dziurawiec, \& R. C. Annis (Eds.), Expiscations in cross-cultural psychology (Lisse, Netherlands: Swets \& Zeitlanger).

King, P. and Kitchener, K. (1994) Developing Reflective Judgment: Understanding and Developing Intellectual Growth and Critical Thinking (San Francisco: Jossey-Bass).

Kitchener, K. S. and King, P. M. (1981). Reflective judgment: concepts of justification and their relationship to age and education. Journal of Applied Developmental Psychology, 2(2), pp. 89-116.

Kitchener, K. S.; Lynch, C. L.; Fischer, K. W.; and Wood, P. K. (1993). Development range of reflective judgment: the effect of contextual support and practice on developmental stage. Developmental Psychology, 29(5), pp. 893-906.

Manninen, A. (1997). Critical reading in accounting. Accounting Education, 6(4), pp. 281-294.

Meyer, B. (2003). Text coherence and readability. Topics in Language Disorders, 23(3), pp. 204-224.

Mingers, J. (2000). What is to be critical? Teaching a critical approach to management undergraduates. Management Learning, 31(2), pp. 219-237.

National Business Education Association - NBEA (2001). National Standards for Business Education (Reston: NBEA).

Ng, J., Lloyd, P., Kober, R., \& Robinson, P. (1999). Developing writing skills; A large class experience: a teaching note. Accounting Education, 8(1), pp. 47-55. 
Paisey, C. and Paisey, N. (2004). An analysis of accounting education research in accounting education: An international journal - 1992-2001. Accounting Education, 13(1), pp. 69-99.

Perry, W. G., Jr., (1970). Forms of Intellectual and Ethical Development in the College Years: A Scheme (New York: Holt, Rinehart, and Winston).

Pintrich, P., Smith, D., Garcia, T., \& McKeachie, W. (1991). A manual for the use of the motivated strategies for learning questionnaire (MSLQ), (Technical Report No. 91-B-004), (Ann Arbor, MI: The Regents of The University of Michigan).

Rea, L. M. and Parker, R. A. (1997). Designing and conducting survey research $\left(2^{\text {nd }}\right.$ ed.), (San Francisco: Jossey-Bass).

Sormunen, C. \& Chalupa, M. (1994). Critical thinking skills research: Developing evaluation techniques. Journal of Education for Business, 69(3), pp. 172-177.

Springer, C. W. and Borthick, A. F. (2004). Business simulation to stage critical thinking in introductory accounting: Rationale, design, and implementation. Issues in Accounting Education, 19(3), pp. 277-303.

Stone, D. N. and Shelley, M. K. (1997). Education for accounting expertise: A field study. Journal of Accounting Research, v.35, Supplement 1997, pp. 35-61.

Vygotsky, L.S. (1978). Mind in Society. (Cambridge, MA: Harvard University Press).

Wilson, R. (2002). Accounting education research: A retrospective over ten years with some pointers to the future. Accounting Education, 11(4), pp. 295-310. 